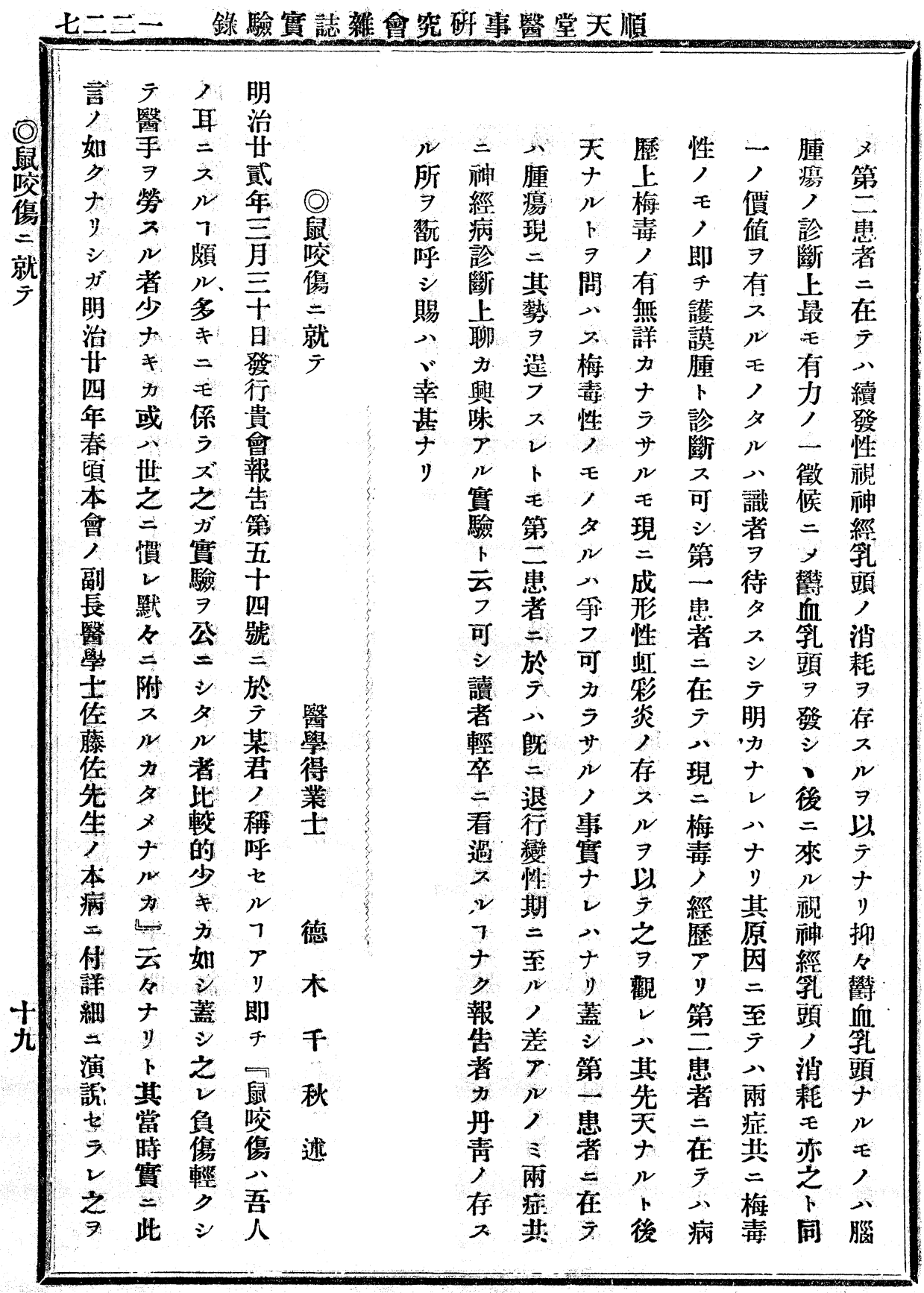


號四十六百二第誌雑會究研事醫堂天順八二二一

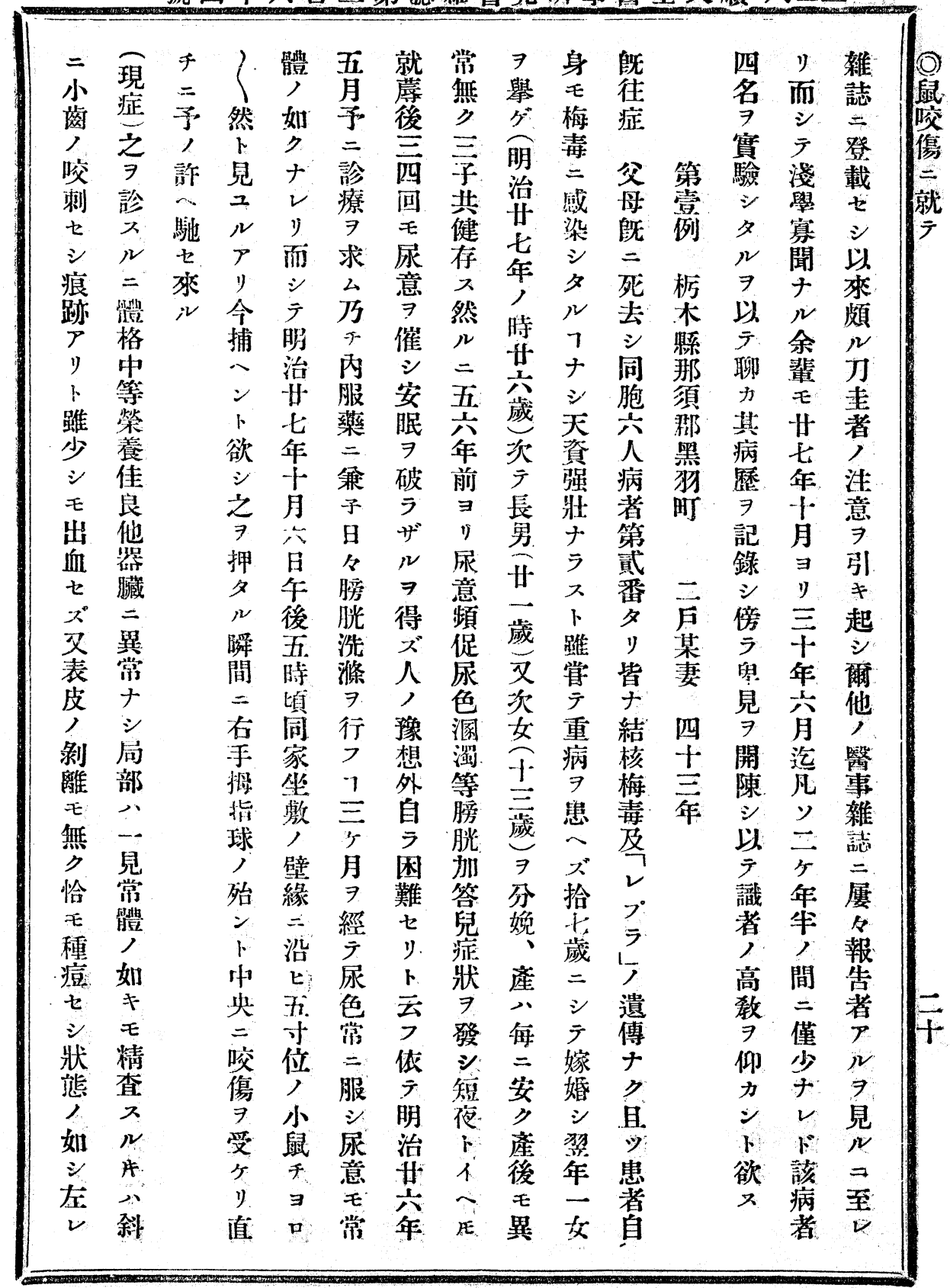


九二二一 錄驗實誌囃會究研事醫堂天㮌

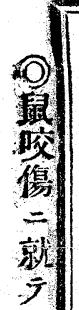

ナ障日皮隆四入良シニナヨト

力害 $\Rightarrow$ 膚起旦 $几$, 違り約本

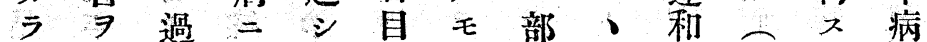

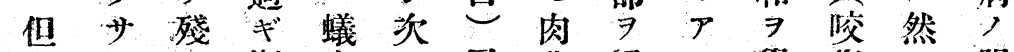

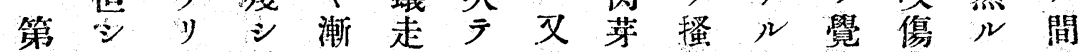

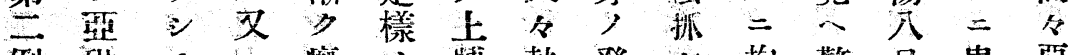

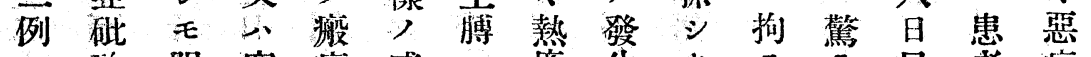

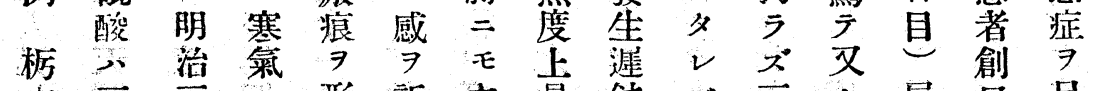

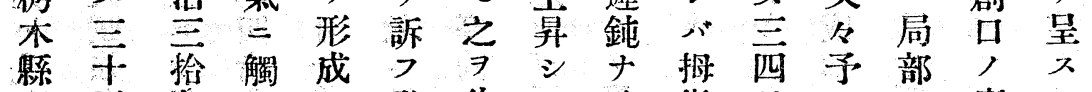

非五年と

須

郡 間

墨持 ナ寒五或週九y容過所大

狗續

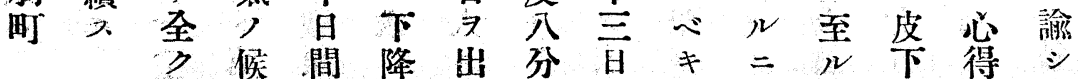

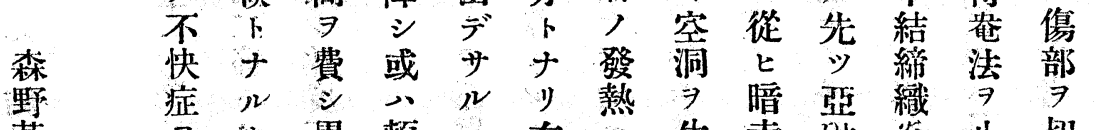

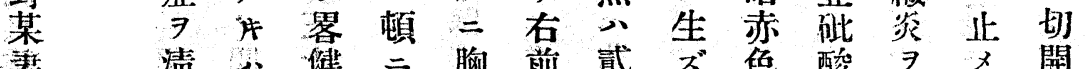
淒埨

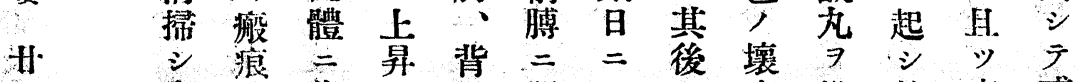

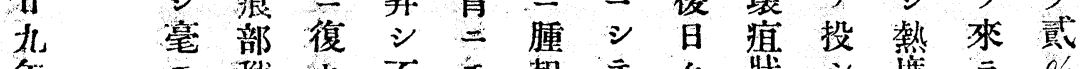

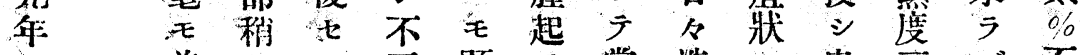

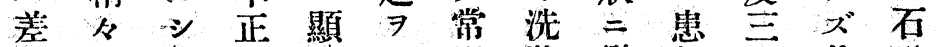

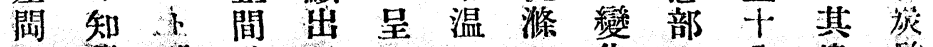

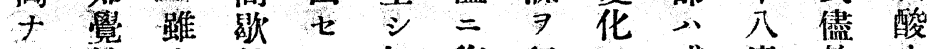

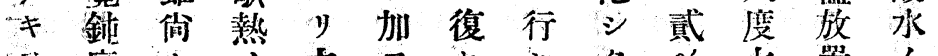

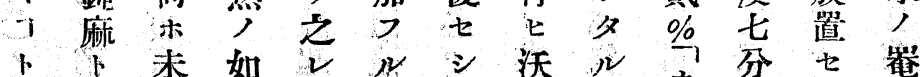

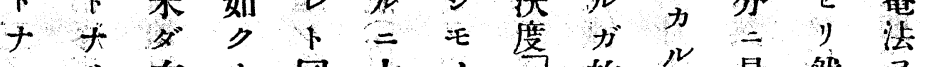

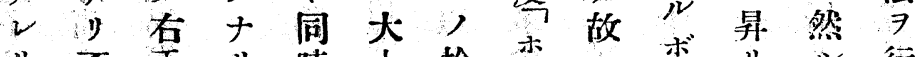

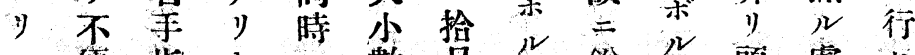

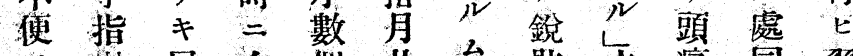

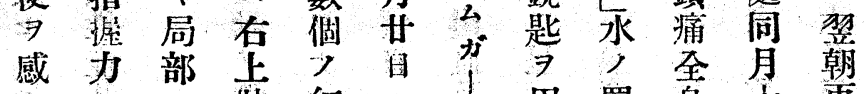

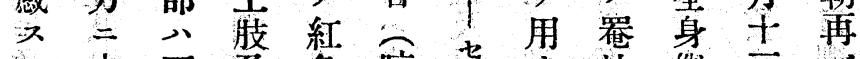

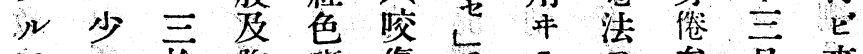

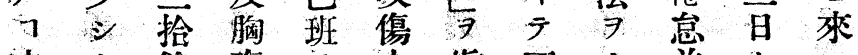

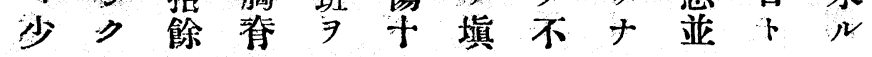


號四十六百二第誌維會究研事醫堂天順 $O$ 三二一

\begin{tabular}{|c|c|c|c|c|c|c|c|c|c|c|c|c|c|c|}
\hline 近 & 右 & 夕 & 術 & $N$ & 裘 & 外 & 蜂 & $z$ & 局 & $=$ & $\#$ & 起 & 染 & 文 \\
\hline 時 & 前 & 創 & $=$ & 7 & 日 & $z$ & 窝 & 7 & 部 & 介 & 九 & シ & 七 & BE \\
\hline 鼠 & 膊 & 面 & 際 & r & r & $\exists$ & 織 & 診 & 湓 & 七 & 年 & 易 & シ & 健 \\
\hline$=$ & 腫 & 3 & シ & 思 & + & 起 & 炎 & $\pi$ & \& & ザ & 兵 & $\neq$ & 7 & 存 \\
\hline 咬 & 脹 & 手 & 左 & 七 & リ & $\pi$ & 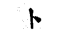 & 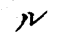 & 腫 & $y$ & 月 & , & ナ & 闹 \\
\hline 傷 & シ & 當 & 程 & $z$ & 承 & I & 診 & $=$ & 起 & シ & 九 & $\Sigma$ & シ & 胞 \\
\hline$\exists$ & 且 & F & 疼 & v & 諾 & 㙰 & 定 & 體 & $\pi$ & 同 & 日 & + & 而 & 二 \\
\hline 受 & \% & 行 & 痛 & $=$ & シ & 合 & シ & 格 & $N$ & + & 右 & 我 & $y$ & 人 \\
\hline ケ & 數 & 7 & $\Rightarrow$ & 何 & タ & $P$ & $z$ & 中 & ガ & $\rightarrow$ & 第 & 歲 & 天 & 兄 \\
\hline タ & 個 & 0 & 感 & $y$ & ル & $N$ & $v$ & 等 & 故 & 日 & 四 & $=$ & 賦 & $\therefore$ \\
\hline$N$ & 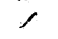 & + & 知 & 圖 & $=$ & 7 & ガ & 營 & $=$ & 午 & 指 & , & 强 & 先 \\
\hline , & 暗 & 四 & 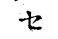 & 5 & $\exists$ & 覺 & 原 & 養 & 子 & 後 & 背 & 婿 & 壯 & 年 \\
\hline 有 & 赤 & 日 & ザ & ע & リ & ح & 因 & 佳 & $=$ & - & 面 & 7 & ナ & 膓 \\
\hline 無 & 色 & $\exists$ & $N$ & 出 & 長 & ズ & タ & 良 & 往 & 時 & 第 & 迎 & ラ & 窒 \\
\hline$\Rightarrow$ & J & リ & $=$ & 血 & 經 & ト & ル & $\gamma$ & 診 & 惡心 & $\rightarrow$ & $\pi$ & ザ & 扶 \\
\hline 問 & 班 & + & 付 & 極 & $=$ & 云 & へ & 婦 & $\Rightarrow$ & 寒 & 節 & 長 & $N$ & 斯 \\
\hline 7 & 點 & t & 茉 & $x$ & 沿 & 7 & f & 人 & 求 & 戰 & p & 女 & 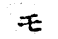 & $=$ \\
\hline 彼 & $\Rightarrow$ & 百 & 熟 & テ & 匕 & 依 & $\exists$ & $=$ & 厶 & 慄 & 第 & I & 敢 & テ \\
\hline$v$ & 現 & $\nabla$ & + & 僅 & 凹 & $\bar{J}$ & 尋 & シ & & $\ddot{*}$ & 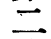 & $I$ & $\bar{\gamma}$ & 死 \\
\hline 熟 & 出 & $\bar{\gamma}$ & $N$ & 微 & 仙 & 病 & 又 & $\bar{\gamma}$ & & 熱 & 節 & 齿 & 重 & x \\
\hline 考 & 즛 & 異 & 予 & $=$ & 迷 & 者 & $N$ & 諸 & & 度 & P & 咸 & 病 & 結 \\
\hline シ & 是 & 常 & $\exists$ & シ & 深 & $=$ & $=$ & 器 & & $\equiv$ & , & 長 & $\exists$ & 核 \\
\hline テ & $=$ & ナ & シ & $\bar{\gamma}$ & ク & 告 & 發 & 臟 & & + & 間 & 男 & 患 & 梅 \\
\hline 日 & 於 & シ & テ & 少 & 骨 & $\eta^{\circ}$ & 病 & $=$ & & 九 & $=$ & $\stackrel{2}{3}$ & $\sim$ & 毒 \\
\hline$\eta$ & $\bar{\gamma}$ & 0 & 疑 & シ & 膜 & $N$ & $\equiv$ & 異 & & 度 & 於 & 胥 & ス & 及 \\
\hline 然 & 初 & + & 惑 & 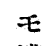 & $\nabla$ & $=$ & 日 & 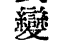 & & 公 & $\overline{\mathcal{J}}$ & 咸 & 只 & \\
\hline$y$ & $\bar{T}$ & 八 & $\exists$ & 濃 & デ & 切 & 以 & + & & 分 & 少 & 及 & 時 & $\checkmark$ \\
\hline 發 & 他 & 日 & 抱 & 液 & 截 & 開 & 前 & シ & & $=$ & シ & 次 & $r$ & $=$ \\
\hline 病 & $=$ & 又 & 力 & + & 開 & x & - & 局 & & 上 & D & 男 & y & ? \\
\hline \# & 原 & \$ & シ & , & シ & $N$ & 日 & 部 & & 昇 & 腫 & $\stackrel{\overbrace{}}{=}$ & 感 & T \\
\hline 四 & 因 & 臨 & $\triangle$ & 内 & タ & , & 閒 & $\therefore$ & & シ & 起 & 蛋 & 䏴 & 遺 \\
\hline 日 & $\gamma$ & 寒 & 0 & 部 & リ & 必 & 田 & 腫 & & 頭 & i & 嵗 & : & 傳 \\
\hline 前 & $N$ & 發 & 同 & 組 & 其 & 要 & 植 & 起 & & 痛 & 㮐 & $\gamma$ & 易 & ナ \\
\hline 即 & 7 & 熱 & 月 & 織 & 時 & 7 & 贲 & シ & & 煩 & 疼 & $\equiv$ & $\neq$ & $\eta$ \\
\hline 五 & 悟 & シ & + & $\rightarrow$ & 多 & 以 & 啝 & 稍 & & 渴 & 痛 & $\overrightarrow{7}$ & r & x \\
\hline 今 & リ & $\bar{\gamma}$ & $\equiv$ & 蠟 & 少 & $\bar{\jmath}$ & 抻 & \& & & 等 & $\Rightarrow$ & $\Rightarrow$ & 夏 & 自 \\
\hline+ & 患 & $\Xi$ & 日 & 色 & $\zeta$ & x & 脞 & 波 & & 爇 & 發 & 擧 & 時 & 5 \\
\hline 六 & 者 & + & $\therefore$ & $\Rightarrow$ & 出 & 當 & $\Rightarrow$ & 動 & & 性 & 七 & グ & 胃 & 学 \\
\hline 日 & $=$ & 九 & 熱 & 呈 & 血. & 日 & ナ & $\Rightarrow$ & & 症 & $\geqslant$ & 然 & 膓 & $\bar{\zeta}$ \\
\hline 巨 & 質 & 度 & 度 & i & 及 & $>$ & 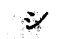 & 觸 & & 狀 & 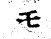 & $N$ & 加 & 梅 \\
\hline 积路 & 8 & 1 & T & 剩 & 混 & 肯 & \$ & $N$ & & $\exists$ & 敢 & $=$ & 答 & 毒 \\
\hline 7 & $\pi$ & + & 降 & $\sim$ & 膿 & 七 & $N$ & 万 & & 訴 & $\bar{\jmath}$ & 明 & 兒 & $=$ \\
\hline 開 & $=$ & $y$ & 日 & 手 & $T$ & ズ & 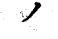 & $f$ & & 0 & 意 & 治 & 7 & 咸 \\
\hline
\end{tabular}




\section{一三二- 錄驗實誌雜會究研事醫堂天䐓}

\begin{tabular}{|c|c|c|c|c|c|c|c|c|c|c|c|c|c|c|}
\hline 廼 & & 擘 & $>$ & 者 & タ & 他 & 脹 & 力 & 面 & 部 & 是 & э & $N$ & $\neq$ \\
\hline H & & $\Rightarrow$ & 熱 & 3 & $=$ & 臹 & $\pi$ & 如 & 金 & $\rightarrow$ & 亦 & $y$ & 愿 & \& \\
\hline 健 & & 離 & 發 & \pm & 前 & $=$ & 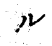 & シ & $\Rightarrow$ & 肉 & 買 & 郖 & 因 & $\nu$ \\
\hline 存 & & $N$ & $=$ & 3 & 記 & 轉 & 1 & 0 & 表 & 芽 & 法 & 哳 & 7 & $\therefore$ \\
\hline 遺 & 第 & , & > & 2 & 1 & i & 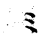 & 七 & 皮 & $\exists$ & $\Rightarrow$ & 酸 & 先 & 内 \\
\hline 德 & $\equiv$ & $=$ & 殊 & 苦 & 紅 & タ & ナ & 月 & $\Rightarrow$ & 充 & 行 & 九 & $\neq$ & $=$ \\
\hline 病 & 例 & 至 & $=$ & 惱 & 班 & $\neq$ & 5 & 甘 & 結 & 夕 & 7 & 7 & $=$ & - \\
\hline+ & & $\vec{N}$ & 安 & 症 & $\Rightarrow$ & 댚 & ズ & 日 & $7^{\circ}$ & x & 熱 & 投 & 探 & 小 \\
\hline \& & 杤 & 其 & 知 & $=$ & 呈 & $=$ & 胸 & $\exists$ & 0 & $\Rightarrow$ & 菨 & $\dot{~}$ & 問 & 鼠 \\
\hline 性 & 木 & 後 & 比 & 屬 & i & \% & 部 & 1) & 七 & E. & 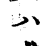 & 腫 & シ & , \\
\hline 質 & 聫 & 格 & 林 & $\pi$ & 劇 & $\neq$ & 声 & 前 & 月 & $\bar{\gamma}$ & 或 & 脹 & 得 & $P$ \\
\hline 怜 & 那 & 别 & $y$ & 後 & 甚 & 學 & $=$ & 症 & $\bar{\Xi}$ & 嘗 & $\rightarrow$ & 部 & ザ & $N$ \\
\hline 剩 & 須 & 再 & 頓 & 脊 & ; & 友 & 背 & 再 & 日 & 藥 & 常 & $=$ & y & 有 \\
\hline , & 郡 & 發 & 腹 & $\mathcal{E}$ & 頙 & 磯 & 部 & 發 & $\exists$ & $\Rightarrow$ & 温 & 向 & i & y \\
\hline 量 & 黑 & $\pi$ & 佳 & 亞 & 痛 & 君 & $=$ & シ & り & 貼 & $=$ & $\bar{J}$ & $\rightarrow$ & 之 \\
\hline 兒 & 旸 & 徵 & 效 & 砒 & $\Rightarrow$ & $=$ & ₹ & - & 買 & $\pi$ & 復 & $=$ & 粗 & $\exists$ \\
\hline$=$ & 朾 & ナ & $\Rightarrow$ & 酸 & 覺 & 依 & 暗 & 旦 & 法 & 0 & $\approx$ & $\%$ & 漏 & 追 \\
\hline : & & i & 奏 & 3 & $\therefore$ & 托 & 赤 & 手 & $\exists$ & \# & 或 & $\rightarrow$ & 不 & 拂 \\
\hline ₹ & & & シ & 用 & 夜 & ㅈ & 色 & 指 & 中 & 五 & $\rightarrow$ & ני & 面 & $\therefore$ \\
\hline 體 & 吉 & & タ & $\mathrm{E}$ & 間 & 其 & l & 創 & it: & A & 夕 & ボ & 目 & ע \\
\hline 格 & ון & & y & 發 & 兩 & 際 & 斑 & 面 & * & 前 & 刻 & 小 & 全 & r \\
\hline 强 & 某 & & t & 埶 & 足 & $j$ & 點 & 3 & 亞 & 膊 & 夜 & $\mu$ & 更 & X \\
\hline 壯 & 長 & & 聞 & 時 & 踇 & 症. & $\Rightarrow$ & 成 & 砒 & 及 & 間 & 水 & 報 & $N$ \\
\hline+ & 男 & & 3 & 頭 & $=$ & 侯 & 生 & 形 & 酸 & 1 & 突 & 悬 & 告 & 時 \\
\hline$y$ & & & 斯 & 部 & 灼 & $\rightarrow$ & シ & 七 & 九 & 膊 & 然 & 法 & $\pi$ & 該 \\
\hline 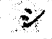 & 七 & & 1 & 水 & 熱 & 夜 & - & 2 & 7 & $J$ & 四 & 7 & $n$ & 部 \\
\hline カ & 年 & & 如 & 罨 & 3 & 分 & 觀 & 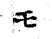 & 如 & 腫 & + & 命 & $=$ & $=$ \\
\hline 本 & & & $\neq$ & 法 & 感 & 熱 & $v$ & , & 法 & 脹 & 度 & 주 & 當 & 咬 \\
\hline 年 & & & 發 & 7 & 覺 & 度 & & 表 & 罾 & 少 & 内 & 0 & $y$ & 傷 \\
\hline$\hbar$ & & & 症 & + & $T$ & $\equiv$ & 5 & 皮 & 量 & $\approx$ & 外 & \# & 實 & 3 \\
\hline 月 & & & \pm & シ & "y & + & 5 & 㔀 & \pm & D & 1 & $\bar{T}$ & $=$ & 受 \\
\hline 九 & & & 數 & 俀 & 此 & 九 & 患 & 離 & 5 & 减 & 發 & 日 & 懒 & ケ \\
\hline 日 & & & 回 & 5 & 顕 & 度 & 者 & シ & 持 & 退 & 熱 & 右 & 槐 & 夕 \\
\hline 右 & & & 7 & 沃 & 痛 & 厉 & $=$ & $\bar{\gamma}$ & 續 & $\pi$ & $P$ & $\frac{1}{1+0}$ & $=$ & $y$ \\
\hline 置 & & & y & 别 & 1 & 育 & 彷 & 潰 & セ & 0 & y & 膊 & 堪 & $\stackrel{1}{ }$ \\
\hline 外 & & & $t$ & 多 & 足 & 世 & 彿 & 瘍 & $\approx$ & $七$ & 0 & $F$ & $\sim$ & 云 \\
\hline 端 & & & 月 & 量 & 蹗 & + & \& & 面 & 么 & 月 & $\#$ & 同 & ボ & \\
\hline 7 & & & $H$ & $=$ & 灼 & 度 & y & 7 & 諸 & $\rightarrow$ & $\equiv$ & 榡 & - & 此 \\
\hline 值 & & & 11 & 機 & 熱 & 7 & 0 & 呈 & 椗 & 日 & 旦 & 侵 & 㨁 & 最 \\
\hline t & & & 頃 & 那 & 3 & 昇 & 八 & i & 輕 & 手 & 手 & 警 & + & $\varepsilon$ \\
\hline$=$ & & & 嬱 & 煎 & 感 & 除 & 月 & 右 & 快 & 指 & 指 & Ł & $=$ & 緊 \\
\hline 鼠 & & & $y$ & 9 & $\rightarrow$ & 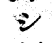 & 八 & 肢 & 2. & 1 & 切 & 5 & 本 & 要 \\
\hline 咬 & & & 病 & 與 & 病 & 所 & 日 & 腫 & N & 釗 & 開 & N & G & $F$ \\
\hline
\end{tabular}


號四十六百二第誌雜會究的事醫堂天順二三二-

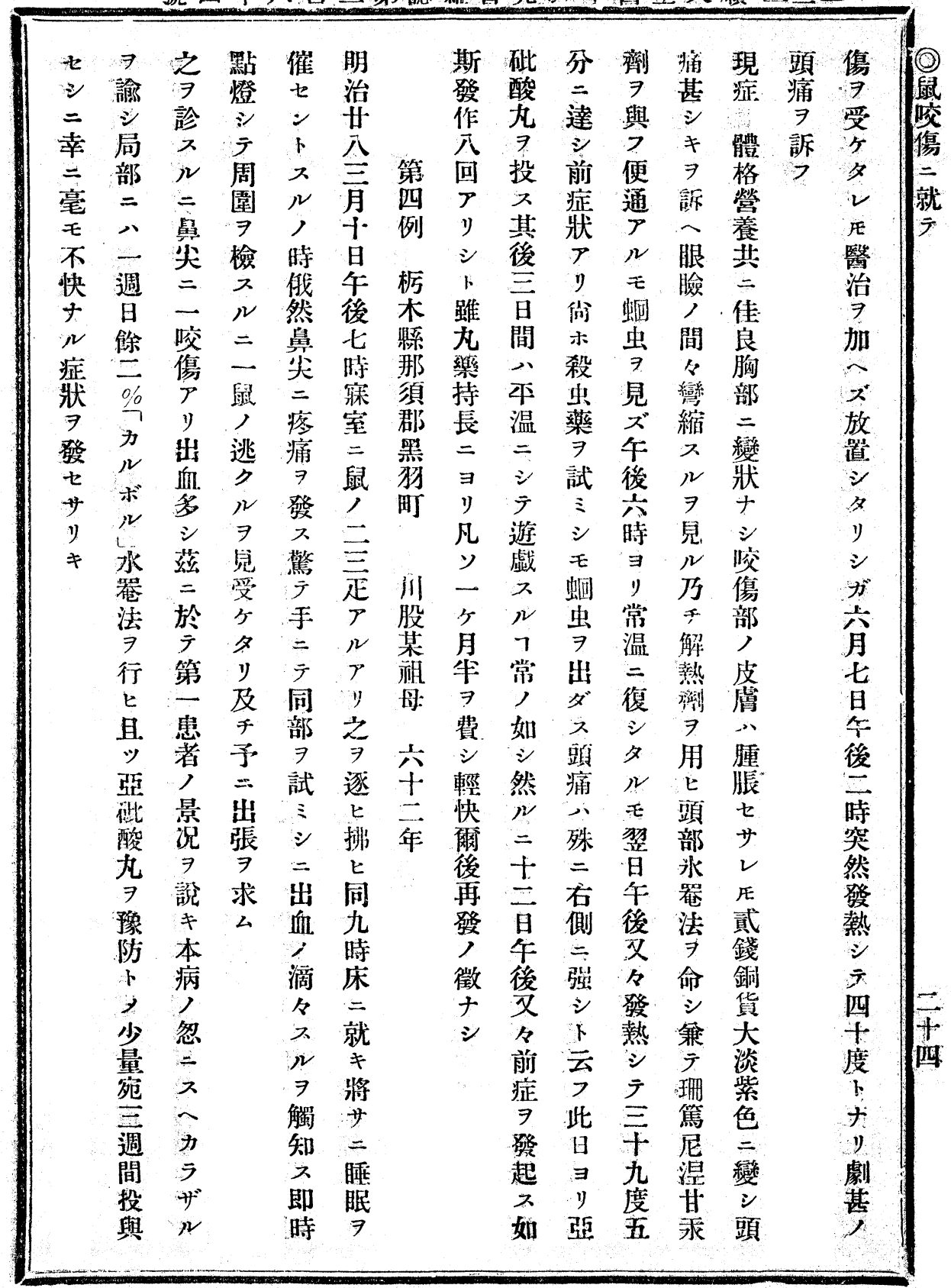


三三二- 錄驗實誌雜會究研事醫堂无順

间生他本々以去

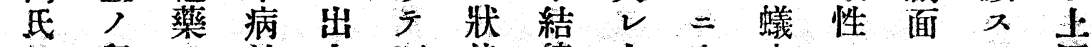
, 鼠, 治血不態締八止走, 一, 西 許咬 發療, 幸等 織, 二傷見藥夕 $=$ 内咬 $y$ 感熱異 7

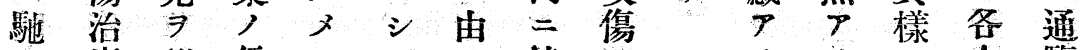
七 療 㲎 信 $=\bar{\nabla}$ 達 $=$ y,

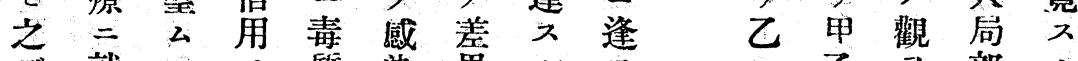

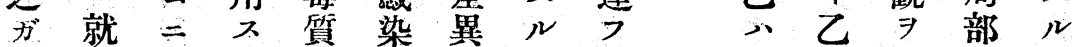
治于切

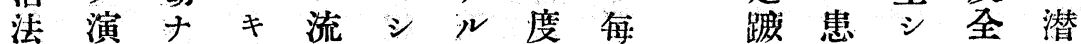
$\exists$ 證 $心$, 出毛毛回昫肢丙身伏 叫七, 沉七, 光必熱腫召症期

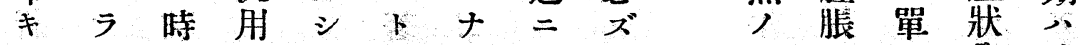
* $v$ 偶 $x=$ 推 $ラ$ 随毒 感 $シ$ 全第 二シ \& 速 7 本亞 $=\exists$ 年䂣 $サ ゙$ 記 感挀肢銅一者

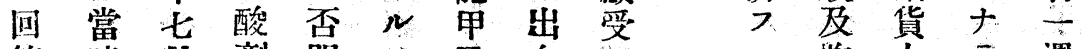
答 時 月 劑 明 7 乙 血 入 $\Rightarrow$ 發榞 並言得丙厂 賜 行

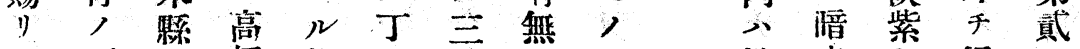

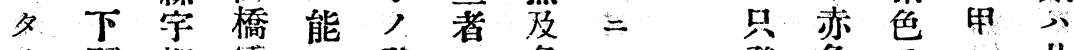

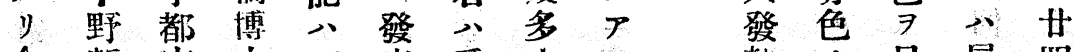
今 澵窝士 ズ症受少 之聞醫分七傷

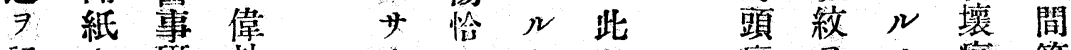

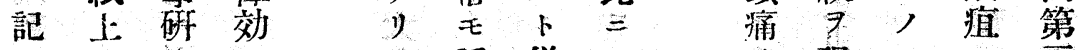

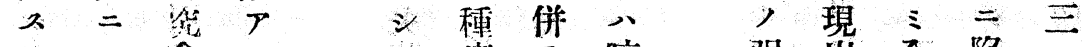

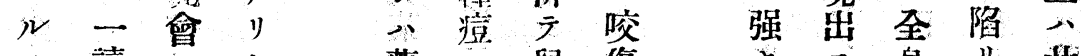
$=$ 讀 $=1 \quad$ 藥 $=$ 鼠傷 $\neq$ 入身紧

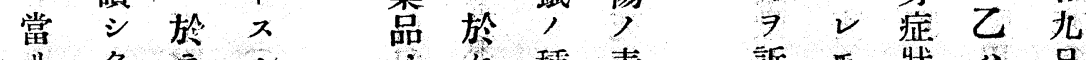

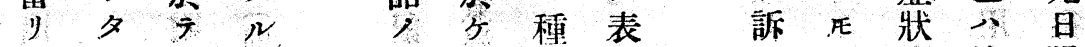

○丙三蜂間 眼 心䆟 ナ

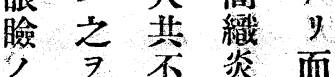

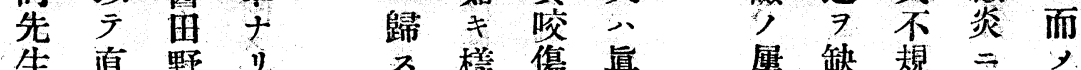

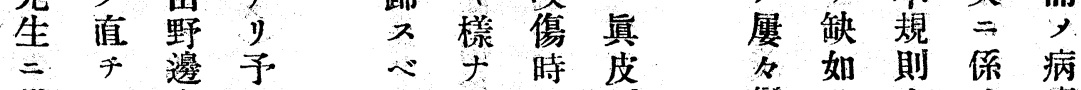

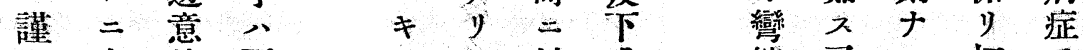

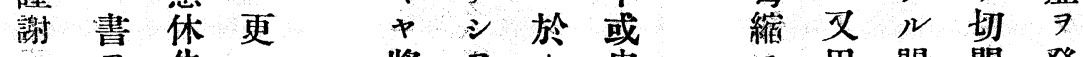
入 先 $=$ 將 $\Rightarrow$ 多皮開發 
號四十六百二第誌雜會究研事醫虽灭順四三二-

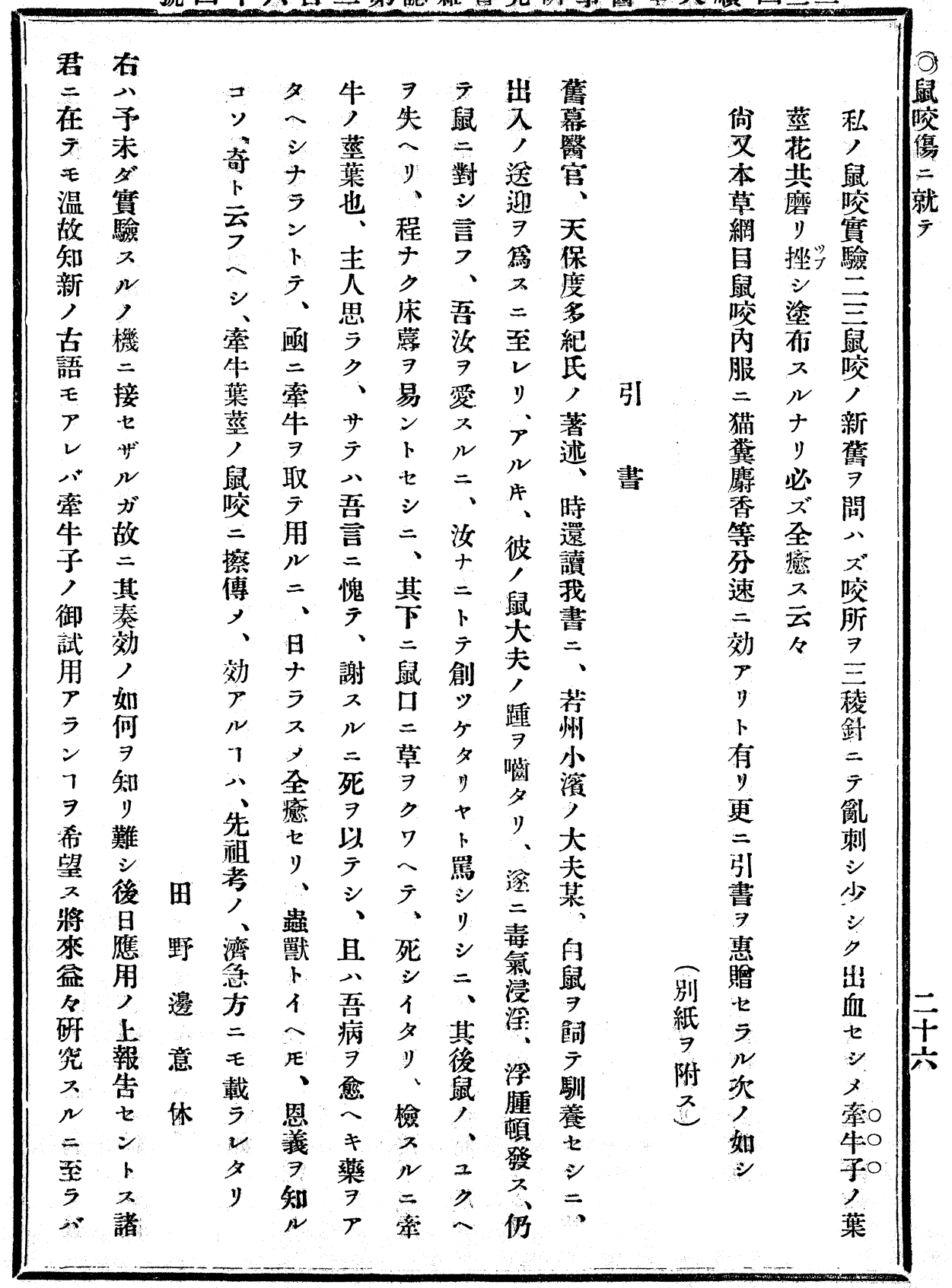


五三二一錄抄誌雑會究研事醫堂天順

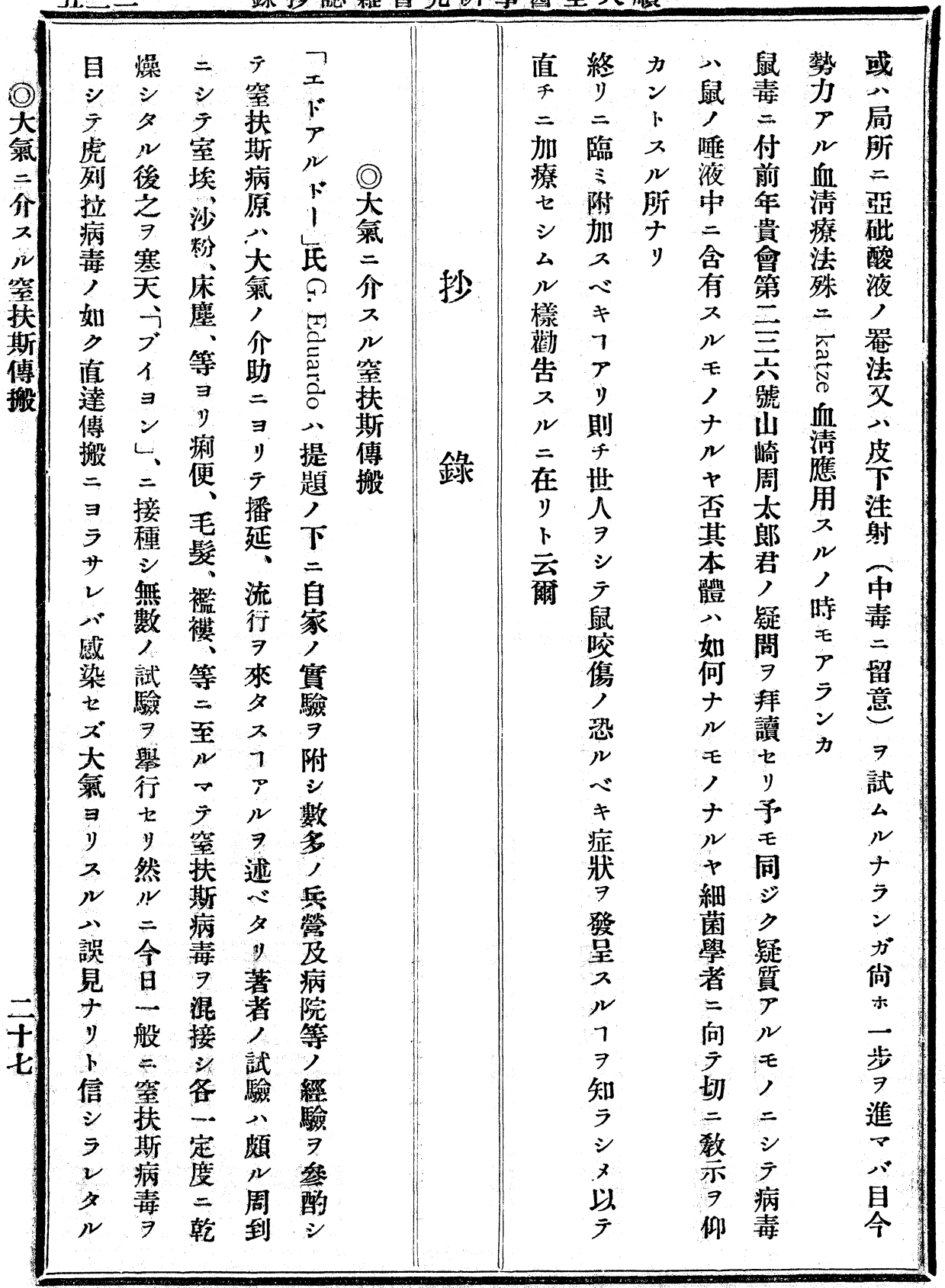

